\title{
EVALUATION OF TRACTIVE PERFORMANCE OF FOUR AGRICULTURAL TRACTORS IN LATERALLY INCLINED TERRAIN
}

\author{
FABRICIO LEITE ${ }^{1}$, JOÃO E. G. DOS SANTOS ${ }^{2}$, KLEBER P. LANÇAS ${ }^{3}$, \\ JOÃO B. LEITE JÚNIOR ${ }^{4}$
}

\begin{abstract}
The present work aimed to evaluate the tractive performance of four agricultural tractors with auxiliary front traction in function of six lateral inclinations in a lateral track of trials, which belongs to the Agronomic Sciences Faculty from the São Paulo State University, Campus of Botucatu. The lateral inclinations were $0 ; 5 ; 10 ; 15 ; 20$ and 25 degrees. In all of these situations, the tractors operated with predetermined load of an imposed traction to the pulled tractor of $40 \mathrm{kN}$ in the inclination of 0 degrees. Hence a delineation in random blocks was used, considering six inclinations and four tractors, and with three repetitions for each treatment. The analyzed variables were slippage, tractive force, hourly fuel consumption, and speed. It was concluded that the pneumatic tire configurations influenced in the tractive performance of the tractors, as they increased the lateral inclinations of the terrain.
\end{abstract}

KEYWORDS: tractive force, slippage, lateral steepness.

\section{AVALIAÇÃO DO DESEMPENHO OPERACIONAL DE QUATRO TRATORES AGRÍCOLAS EM TERRENO INCLINADO LATERALMENTE}

RESUMO: O presente trabalho teve como objetivo avaliar o desempenho operacional de quatro tratores agrícolas com tração dianteira auxiliar, em função de seis inclinações laterais, em uma pista lateral de ensaios, pertencente à Faculdade de Ciências Agronômicas da Universidade Estadual Paulista, Câmpus de Botucatu. As inclinações laterais foram 0; 5; 10; 15; 20 e 25 graus. Em todas estas situações, os tratores operaram com carga predeterminada de tração imposta ao trator tracionado de $40 \mathrm{kN}$ na inclinação de 0 grau. Portanto, foi utilizado um delineamento em blocos casualizados (DBC), sendo seis inclinações e quatro tratores, e com três repetições para cada tratamento. As variáveis analisadas foram patinhagem, força de tração, consumo horário de combustível e velocidade de deslocamento. Concluiu-se que a configuração dos rodados pneumáticos influenciaram no desempenho operacional dos tratores, conforme aumentaram as inclinações laterais do terreno.

PALAVRAS-CHAVE: força de tração, patinhagem, declividade lateral.

\section{INTRODUCTION}

One of the main functions of agricultural tractors is to transform the energy contained in the fuel and deliver it, through the drawbar, to pull farm machinery and implements. The performance on the drawbar of a tractor depends mainly on engine power, transmission mechanisms, distribution of weight on the wheels, height and position of the coupling bar and the soil surface (GABRIEL FILHO et al., 2010 a).

When GABRIEL FILHO et al. (2010 b) evaluated the performance of one agricultural tractor depending on the wear of the grips of tires and soil surface conditions, he observed that the best tractor performance happened on the firm ground track, and the superficial condition of the mobilized soil was responsible for the worst performance of the tractor.

\footnotetext{
${ }^{1}$ Prof. Dr., Universidade Estadual de Maringá - UEM, Câmpus de Umuarama - PR, Departamento de Máquinas e Implementos.

${ }_{2}^{2}$ Prof. Livre Docente, Faculdade de Engenharia Mecânica - FE/UNESP, Câmpus de Bauru - SP, Depto. de Engenharia Mecânica.

${ }^{3}$ Prof. Titular, Eng ${ }^{\mathrm{o}}$ Mecânico, Faculdade de Ciências Agronômicas - FCA/UNESP, Câmpus de Botucatu - SP, Depto. de Eng. Rural.

${ }^{4}$ Eng $^{\mathrm{o}}$ Agrícola, Prof. Adjunto, Departamento de Agronomia, UEMS, Cassilândia - MS.

Recebido pelo Conselho Editorial em: 3-3-2011

Aprovado pelo Conselho Editorial em: 9-6-2011
} 
Among the factors that interfere with the traction, the slope of the land is also one important factor and, among the soil properties of the terrain that can affect the efficiency of traction of an agriculture tractor, one can mention the texture, water content, and soil superficial conditions.

The imbalance of the reactions in the tires of the tractor, more one side than the other, due to the fact that the last one traffics on an inclined track or to the action of centrifugal force, causes the differences on the tire deformations. These deformations depend on the reactions applied on the tires, which results in the increasing of the lateral inclination of the chassis, in relation to the track, decreasing the stability of the tractor (KHOURY JUNIOR et al., 2009).

Therefore, the awareness of the limit operational slope on the stability of tractors is of great importance in the safety of agricultural operations. In this case, slippage of the tires and the conditions of the ground surface are determining factors in the instability of the tractor, causing a lateral tipping (POTA et al., 2007).

ASABE (2006) recommends obtaining maximum traction efficiency, slippage from 8 to $10 \%$ in not mobilized soils, and from 11 to $13 \%$ in mobilized soils. The rate of $20 \%$ slippage is used by some authors (WULFSOHN et al., 1988) to express the coefficient of net traction when the goal is to compare the performance of tires in the field. However, the rate of $30 \%$ according to BARBOSA et al. (2005) represents extreme loss of energy by the tire, which is impossible to be found in agricultural operations.

According to MÁRQUES (2008), to achieve a traction efficiency of 0.93 on firm ground, the slippage should be between 4 and $8 \%$. However, when the values of slippage grow the efficiency decreases significantly.

MONTEIRO et al. (2009), in several studies, found that adding weight to the tractor, obeying the criteria of the relation between weight and power and capacity of the tire, it leads to improvements in operational efficiency, increase of tractive force, reduction of slippage, the hourly consumption and specific fuel.

According to SERRANO (2007), the main technical indicator for the evaluation of the efficiency of the use of agricultural tractor is the energy estimation carried out based on the measurement of fuel consumption per hour.

GABRIEL FILHO et al. (2010 a), in a study on the influence of the grip height from the tires of a tractor of a $89 \mathrm{~kW}$ nominal power in the engine in an area of tillage, concluded that larger grips kept the slippage of the tractor, even with the increase of displacement speed, and the tires with lower grips seem to have adhered better to the soil, which decreased the slippage at the slowest speed.

Therefore, the objective of this study was to evaluate the operational performance of four tractors and their behavior as points of support in relation to the lateral inclination of the terrain.

\section{MATERIAL AND METHODS}

The study was conducted at the Lageado Experimental Farm, which belongs to the Faculty of Agricultural Sciences, São Paulo State University, Campus of Botucatu. The tests were performed in a lateral track, part of the NEMPA (Center of Testing of Agroforestry Machinery and Tire), with 400 meters long and 3 meters wide and a slippage of 55.5\%. The geographic coordinates of the experimental area are: $22^{\circ} 51^{\prime} \mathrm{S}$ and $48^{\circ} 25^{\prime} \mathrm{W}$ and altitude of $770 \mathrm{~m}$. The soil was classified, according to EMBRAPA (2006), as Alfisol Distroferric with flat terrain and clayey. The water content and soil density, in the layers from 0 to $20 \mathrm{~cm}$, were $19 \%$ and $1.58 \mathrm{~g} \mathrm{~cm}^{-3}$, respectively.

In Table 1, are some of the technical characteristics of each tractor tested. 
TABLE 1. Technical characteristics of tractors tested.

\begin{tabular}{lcccc}
\hline Features & Tractor 1 & Tractor 2 & Tractor 3 & Tractor 4 \\
\hline Rated motor power $(\mathrm{kW})$ & 158 & 132 & 118 & 89 \\
Gauge $(\mathrm{mm})$ & 2000 & 1673 & 1700 & 1800 \\
Static front tire $(\mathrm{kN})$ & 52.00 & 41.00 & 35.00 & 28.88 \\
Static rear tire $(\mathrm{kN})$ & 71.00 & 63.00 & 53.00 & 43.42 \\
Static total tractor $(\mathrm{kN})$ & 123.00 & 104.00 & 88.00 & 72.30 \\
Rear Tire Size (in.) & $30.5 \mathrm{~L}-32$ & $24.5-32$ & $20.8-38$ & $23.1-30$ \\
Front Tire Size (in.) & $18.4-26$ & $18.4-26$ & $16.9-30$ & $14.9-26$ \\
\hline
\end{tabular}

For the evaluation of operational performance in the lateral slope, four prototypes of tractors were used, where all of them had an equal ballast net of $75 \%$ of the pneumatics capacity. To simulate the load pulled in the form of a convoy, one tractor of $88.94 \mathrm{~kW}(121 \mathrm{cv})$ was used for all the tractors tested.

The acquisition of the signals generated by sensors installed in the tires, in the drawbar and in the fuel supply circuit, was through one electronic panel with power indicator, rotation and fuel consumption of "MICRO-P" type. In determining the force on the drawbar, we used a load cell, brand SODMEX, model N400, with a sensitivity of $2.156 \mathrm{mV} / \mathrm{V}$ and nominal scale of $100 \mathrm{kN}$, which measured the tractive force of the tractor pulling another tractor through a steel cable in the form of a convoy. To evaluate the hourly consumption of fuel, we used one flowmeter manufactured by FLOWMATE OVAL, M-III LSN40 model, with accuracy of $0.01 \mathrm{~mL} \mathrm{pulse}^{-1}$, which emits a pulse unit every milliliter of fuel that passes through it. To measure the speed of displacement, a tape measure, a stopwatch to measure the time of the test, and beacons to mark the distance traveled were used. We used four pulse generators by "S\&E Instrumentos de Testes e Medições", model GIDP-60-U-12V, which generate a relation of 60 pulses per revolution, installed in the front and rear tires of the tractor to measure the rotations.

The tire slippage was calculated by Equation 1.

$$
\mathrm{P}=\left(\frac{\mathrm{nc}-\mathrm{ns}}{\mathrm{nc}}\right) 100
$$

where,

$$
\begin{aligned}
& \mathrm{P} \text { - slippage, } \% \text {; } \\
& \text { nc - rotations from driving wheel, with load, and } \\
& \text { ns - rotations from driving wheel, without load. }
\end{aligned}
$$

The number of rotations of the driving wheel with without load (ns) was obtained during the calibrations on a hard surface. The number of rotations of the driving wheel with load (nc) was obtained with the tractor in the field. (2010 a).

The average tractive force was determined by Equation 2, according to GABRIEL FILHO

$$
F_{m}=\frac{\sum_{i=1}^{n} F i}{n}
$$

where,

$\mathrm{F}_{\mathrm{i}}$ - instant tractive force, $\mathrm{kN}$;

$\mathrm{F}_{\mathrm{m}}$ - average tractive force, $\mathrm{kN}$, and

$\mathrm{n}$ - number of recorded data. 
The fuel consumption was calculated by Equation 3 .

$$
\mathrm{Cc}=\frac{\sum_{\mathrm{p}} 3,6}{\Delta_{\mathrm{t}}}
$$

where,

$\mathrm{C}_{\mathrm{c}}$ - hourly fuel consumption, $\mathrm{L} \mathrm{h}^{-1}$;

$\Sigma_{p}$ - sum of pulses, equivalent to the sum of $\mathrm{mL}$ of the fuel spent to traverse the experimental portion, $\mathrm{mL}$;

$\Delta_{\mathrm{t}}$ - time taken to traverse the experimental portion, $\mathrm{s}$, and

3.6 - conversion factor.

The experimental delineation was conducted with the tractor moving longitudinally on its left side with respect to the lateral inclination of the track. The lateral inclinations were $0 ; 5 ; 10 ; 1520$ and 25 degrees, as can be seen in Figure 1, which used an inclinometer installed in the panel to guide and keep the tractors at each inclination. In all cases, the tractors operated with a predetermined traction load imposed on the pulled tractor of $40 \mathrm{kN}$ on and inclination of 0 degrees. We used delineation in random blocks (DBC), considering six (6) inclinations and four (4) tractors, with a total of twenty-four (24) treatments and three (3) repetitions for each treatment. Thus, we used seventy-two (72) experimental units.

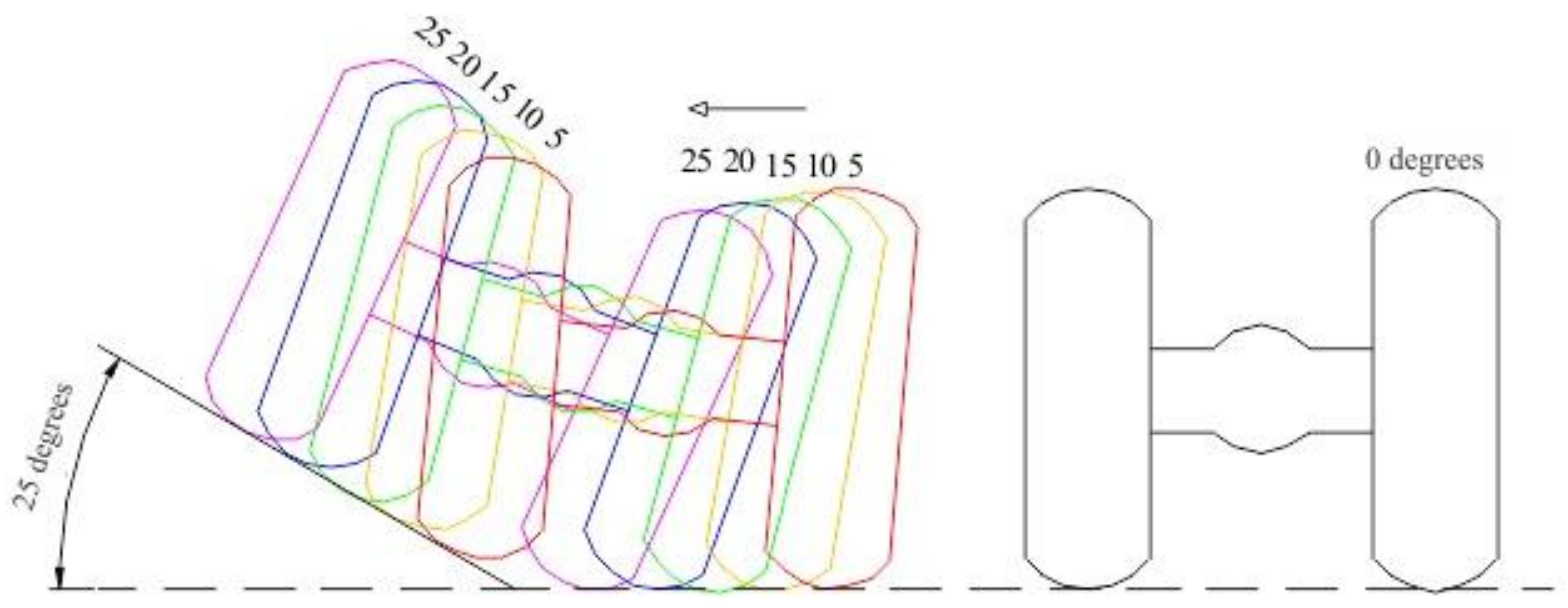

FIGURE 1. Sketch of the slopes evaluated from tractors to travel on the track side.

\section{RESULTS AND DISCUSSION}

Table 2 shows the average values run of slippage on the right-side tires, left-side tires, and total slippage tractors relating to the lateral inclination of the track. According to the results presented in Table 2, the slippage of the right-side tires increased with increasing of the lateral inclination of the track to the tested tractors, except for the tractor $\mathrm{T} 4$, which obtained a minor slippage on the 25 degrees inclination on the tests of lateral track, which can be attributed to the greater weight transfer for the occurrence of the displacement of the center of gravity to the right side, due to increased lateral inclination of the track, according to KHOURY JUNIOR et al. (2009). The T1 tractor was the only one whose slippage of the right-side tires was in the range of maximum tractive efficiency until the inclination of 10 degrees, according to MÁRQUES (2008), and 15 degrees forward, as ASABE (2006). The T3 tractor had the highest slippage on the inclination of 25 degrees, which can also be attributed to the fact the tractor is equipped with a larger rim tire and a narrow tread, as can be seen in Table 1 .

Observing the values shown in Table 2, the medium slippage of the left-side tires increased with the increasing of the lateral inclination of the test track for all tractors, showing a quite high increase in the slippage because of the transfer of lateral weight shifted to the right-side of tractors, losing the tire/ground contact, according to KHOURY JUNIOR et al. (2009). 
The tractor T4 provided the smallest increase in the slippage of the left-side tires, equal to 259.7\%; however it was the tractor that had the highest slippage on the inclinations of 15 and 20 degree of the lateral track of tests, thus losing a lot of energy by the tire. The same happened with the tractor T3, as BARBOSA et al. (2005). According to the results presented in Table 2, the T1 tractor was the one that obtained lower medium slippage of the tires on all the lateral inclinations of the test track. Comparing to other tractors, it was the one in the maximum tractive efficiency range, according to BARBOSA et al. (2005), ASABE (2006) and MÁRQUES (2008).

TABLE 2. Medium values of slippage (\%) in all of the inclinations evaluated for the tractors T1 (158 kW), T2 (132 kW), T3 (118 kW) and T4 (89 kW).

\begin{tabular}{|c|c|c|c|c|c|c|c|}
\hline Tractors & $0^{\circ}$ & $5^{\circ}$ & $10^{\circ}$ & $15^{\circ}$ & $20^{\circ}$ & $25^{\circ}$ & $\mathrm{CV}(\%)$ \\
\hline \multicolumn{8}{|c|}{ Slippage of the right-side tires (\%) } \\
\hline T1 & $4.39 \mathrm{a}$ & $6.25 \mathrm{ab}$ & $7.93 \mathrm{ab}$ & $8.35 \mathrm{~b}$ & $9.89 \mathrm{~b}$ & $9.36 \mathrm{~b}$ & 17.95 \\
\hline $\mathrm{T} 2$ & $8.60 \mathrm{a}$ & $11.21 \mathrm{~b}$ & $11.44 \mathrm{bc}$ & $14.03 \mathrm{~cd}$ & $14.29 \mathrm{~d}$ & $15.53 \mathrm{~d}$ & 7.32 \\
\hline $\mathrm{T} 3$ & $12.36 \mathrm{a}$ & $15.49 \mathrm{ab}$ & $15.50 \mathrm{ab}$ & $17.52 \mathrm{~b}$ & $16.89 \mathrm{~b}$ & $25.11 \mathrm{c}$ & 7.75 \\
\hline $\mathrm{T} 4$ & $11.64 \mathrm{a}$ & $17.58 \mathrm{~b}$ & $17.58 \mathrm{~b}$ & $11.64 \mathrm{a}$ & $8.22 \mathrm{a}$ & $6.73 \mathrm{a}$ & 16.01 \\
\hline \multicolumn{8}{|c|}{ Slippage of the left-side tires (\%) } \\
\hline $\mathrm{T} 1$ & $4.19 \mathrm{a}$ & $7.52 \mathrm{ab}$ & $9.24 \mathrm{~b}$ & $8.74 \mathrm{~b}$ & $10.61 \mathrm{~b}$ & $17.32 \mathrm{c}$ & 15.42 \\
\hline $\mathrm{T} 2$ & $8.39 \mathrm{a}$ & $12.26 \mathrm{ab}$ & $13.83 \mathrm{ab}$ & $17.04 \mathrm{~b}$ & $18.10 \mathrm{~b}$ & $33.30 \mathrm{c}$ & 15.54 \\
\hline $\mathrm{T} 3$ & $12.97 \mathrm{a}$ & $22.78 \mathrm{~b}$ & $22.59 \mathrm{~b}$ & $28.05 \mathrm{~b}$ & $28.57 \mathrm{~b}$ & $54.32 \mathrm{c}$ & 8.27 \\
\hline $\mathrm{T} 4$ & $11.61 \mathrm{a}$ & $15.38 \mathrm{ab}$ & $20.39 \mathrm{~b}$ & $36.57 \mathrm{c}$ & $41.48 \mathrm{c}$ & $41.75 \mathrm{c}$ & 9.15 \\
\hline \multicolumn{8}{|c|}{ Medium slippage (\%) } \\
\hline $\mathrm{T} 1$ & $4.29 \mathrm{a}$ & $6.89 \mathrm{ab}$ & $8.59 \mathrm{~b}$ & $8.54 \mathrm{~b}$ & $10.25 \mathrm{bc}$ & $13.34 \mathrm{c}$ & 16.21 \\
\hline $\mathrm{T} 2$ & $8.50 \mathrm{a}$ & $11.73 \mathrm{ab}$ & $12.63 \mathrm{ab}$ & $15.54 \mathrm{~b}$ & $16.19 \mathrm{~b}$ & $24.42 \mathrm{c}$ & 10.83 \\
\hline $\mathrm{T} 3$ & $12.67 \mathrm{a}$ & $19.13 \mathrm{~b}$ & $19.05 \mathrm{~b}$ & $22.78 \mathrm{~b}$ & $22.73 \mathrm{~b}$ & $39.72 \mathrm{c}$ & 7.59 \\
\hline $\mathrm{T} 4$ & $11.62 \mathrm{a}$ & $16.51 \mathrm{ab}$ & $18.99 \mathrm{~b}$ & $24.10 \mathrm{c}$ & $24.85 \mathrm{c}$ & $24.24 \mathrm{c}$ & 8.74 \\
\hline
\end{tabular}

Media with equal letters, in the same line, do not differ from each other by the Tukey test $(\mathrm{P}>0.05)$.

Observing Table 2, the medium values of slippage of the T1 tractor that it could get the maximum tractive efficiency were to the lateral inclination of 20 degrees, according to ASABE (2006). Also observing Table 2, above the slippage of 5 degrees, the medium slippage of the tractors $\mathrm{T} 2, \mathrm{~T} 3$ and $\mathrm{T} 4$ were compromised considering the ideal range for maximum tractive efficiency, as ASABE (2006), however, in the lateral inclination of 25 degrees, the tires of the T3 tractor were losing a lot of energy according to BARBOSA et al. (2005).

The results showed (Table 3) that there was a significant decrease in the tractive force for all tractors as the inclinations increased, not maintaining the tractive force of $40 \mathrm{kN}$ applied horizontally, which can be attributed to an lateral weight transfer also increasing run the slippage of the tires. It can be seen in Table 3 that the tractor T1 got the lowest significant differences between the inclinations, which can be attributed to the higher static load on the rear tires, as shown in Table 1 , thereby increasing the tractive force due to the weight transfer, as according to KHOURY JUNIOR et al. (2009).

The tractor T3 had the lowest decrease in tractive force, $12.55 \%$. This lower decrease can be attributed to the fact that the tractor was equipped with a larger rim tire, as Table 1, and according to ZOZ (2007), the larger the radius of the wheel the greater the tractive force. In this case, the T4 tractor, for being equipped with the smallest rim tire, as shown in Table 1, was the one that had the highest decrease, $45 \%$, in tractive force. 
TABLE 3. Medium values of tractive force $(\mathrm{kN})$ in all inclinations evaluated for the tractors $\mathrm{T} 1$ $(158 \mathrm{~kW}), \mathrm{T} 2(132 \mathrm{~kW}), \mathrm{T} 3(118 \mathrm{~kW})$ and T4 $(89 \mathrm{~kW})$.

\begin{tabular}{cccccccc}
\hline Tractors & \multicolumn{1}{c}{$0^{\circ}$} & \multicolumn{1}{c}{$5^{\circ}$} & \multicolumn{1}{c}{$10^{\circ}$} & \multicolumn{1}{c}{$15^{\circ}$} & $20^{\circ}$ & $25^{\circ}$ & CV $(\%)$ \\
\hline & & & \multicolumn{7}{c}{ Tractive force $(\mathrm{kN})$} \\
$\mathrm{T} 1$ & $40.00 \mathrm{a}$ & $39.25 \mathrm{a}$ & $38.18 \mathrm{ab}$ & $36.18 \mathrm{~b}$ & $33.31 \mathrm{c}$ & $30.65 \mathrm{~d}$ & 2.34 \\
$\mathrm{~T} 2$ & $40.00 \mathrm{a}$ & $38.33 \mathrm{ab}$ & $36.33 \mathrm{bc}$ & $34.67 \mathrm{c}$ & $30.50 \mathrm{~d}$ & $23.00 \mathrm{e}$ & 3.43 \\
$\mathrm{~T} 3$ & $40.00 \mathrm{a}$ & $39.86 \mathrm{~b}$ & $38.45 \mathrm{c}$ & $37.48 \mathrm{~d}$ & $36.92 \mathrm{e}$ & $34.98 \mathrm{f}$ & 0.16 \\
$\mathrm{~T} 4$ & $40.00 \mathrm{a}$ & $38.00 \mathrm{~b}$ & $36.50 \mathrm{c}$ & $34.50 \mathrm{~d}$ & $28.83 \mathrm{e}$ & $22.00 \mathrm{f}$ & 1.22 \\
\hline
\end{tabular}

Media with equal letters, in the same line, do not differ from each other by the Tukey test $(\mathrm{P}>0.05)$.

As for the time consumption, as can be seen in Table 4, there was no significant influence of the increase of the terrain inclinations for the tractor T3, and the tractor that showed the highest difference was $\mathrm{T} 1$, which can be attributed to the higher power rating in engine. The higher significant time consumption that the tractor $\mathrm{T} 1$ presented was on zero degree inclination, where this same tractor provided higher tractive force and higher displacement speed, behavior similar to that presented by GABRIEL FILHO et al. (2010 b).

TABLE 4. Medium values of fuel consumption $\left(\mathrm{L} \mathrm{h}^{-1}\right)$ in all inclinations evaluated for the tractors T1 (158 kW), T2 (132 kW), T3 (118 kW) and T4 (89 kW).

\begin{tabular}{cccccccc}
\hline Tractors & $0^{\circ}$ & $5^{\circ}$ & $10^{\circ}$ & $15^{\circ}$ & $20^{\circ}$ & $25^{\circ}$ & $\mathrm{CV}(\%)$ \\
\hline T1 & $27.20 \mathrm{a}$ & $26.45 \mathrm{ab}$ & $25.88 \mathrm{bc}$ & $25.74 \mathrm{bc}$ & $24.95 \mathrm{c}$ & $25.63 \mathrm{bc}$ & 1.54 \\
$\mathrm{~T} 2$ & $22.50 \mathrm{a}$ & $27.40 \mathrm{c}$ & $25.34 \mathrm{~b}$ & $22.86 \mathrm{a}$ & $20.89 \mathrm{a}$ & $21.40 \mathrm{a}$ & 3.09 \\
$\mathrm{~T} 3$ & $21.52 \mathrm{a}$ & $22.23 \mathrm{a}$ & $21.33 \mathrm{a}$ & $22.02 \mathrm{a}$ & $22.29 \mathrm{a}$ & $21.28 \mathrm{a}$ & 2.57 \\
$\mathrm{~T} 4$ & $20.59 \mathrm{ab}$ & $20.27 \mathrm{a}$ & $20.35 \mathrm{a}$ & $21.35 \mathrm{ab}$ & $21.57 \mathrm{~b}$ & $20.55 \mathrm{ab}$ & 2.00 \\
\hline
\end{tabular}

Media with equal letters, in the same line, do not differ from each other by the Tukey test $(\mathrm{P}>0.05)$.

The terrain inclinations that showed significant differences in displacement speed of each tractor (Table 5) were 0 and 25 degrees. The highest speed obtained by the tractors was in the lowest inclination and the lowest speed was presented in the higher terrain inclination, however, the inclinations 0 and 25 degrees had the lowest and highest slippages, as can be seen in Table 2 . The tractive performance of the tractor was influenced by the condition of the ground surface, as evidenced by GABRIEL FILHO et al. (2010 a), in this case the condition of increasing inclinations on firm ground, making more evident in the evaluation of slippage, as can be seen in Table 2 .

TABLE 5. Medium values of speed $\left(\mathrm{k} \mathrm{h}^{-1}\right)$ in all inclinations evaluated for the tractors $\mathrm{T} 1(158 \mathrm{~kW})$, $\mathrm{T} 2(132 \mathrm{~kW}), \mathrm{T} 3(118 \mathrm{~kW})$ and $\mathrm{T} 4(89 \mathrm{~kW})$.

\begin{tabular}{cccccccc}
\hline Tractors & $0^{\circ}$ & $5^{\circ}$ & $10^{\circ}$ & $15^{\circ}$ & $20^{\circ}$ & $25^{\circ}$ & $\mathrm{CV}(\%)$ \\
\hline & & & \multicolumn{2}{l}{ Velocity $\left(\mathrm{km} \mathrm{h}^{-1}\right)$} \\
$\mathrm{T} 1$ & $6.04 \mathrm{a}$ & $5.69 \mathrm{~b}$ & $5.53 \mathrm{~b}$ & $5.58 \mathrm{~b}$ & $5.51 \mathrm{~b}$ & $5.17 \mathrm{c}$ & 2.04 \\
$\mathrm{~T} 2$ & $5.11 \mathrm{a}$ & $4.73 \mathrm{~b}$ & $4.68 \mathrm{~b}$ & $4.45 \mathrm{~b}$ & $4.49 \mathrm{~b}$ & $4.14 \mathrm{c}$ & 2.40 \\
$\mathrm{~T} 3$ & $4.24 \mathrm{a}$ & $4.06 \mathrm{ab}$ & $4.01 \mathrm{ab}$ & $3.87 \mathrm{~b}$ & $3.89 \mathrm{~b}$ & $3.06 \mathrm{c}$ & 2.57 \\
$\mathrm{~T} 4$ & $4.22 \mathrm{a}$ & $4.02 \mathrm{bc}$ & $4.08 \mathrm{ab}$ & $3.89 \mathrm{~cd}$ & $3.94 \mathrm{~cd}$ & $3.82 \mathrm{~d}$ & 1.23 \\
\hline
\end{tabular}

Media with equal letters, in the same line, do not differ from each other by the Tukey test $(\mathrm{P}>0.05)$.

\section{CONCLUSION}

The configurations of the pneumatic tires influence the tractive performance of the tractors, as the increase of the terrain lateral inclinations.

Tractors with lower static load on the tires suffer major influences of the increase of the terrain lateral inclinations in the development of tractive force. 
Tractors with higher static charge on the tires suffer less influence of the increase of the terrain lateral inclinations with regard to slippage.

\section{REFERENCES}

ASABE. AMERICAN SOCIETY OF AGRICULTURAL AND BIOLOGICAL ENGINEERS. ASAE EP496.3 Agricultural Machinery Management. St. Joseph: ASABE Standards, 2006. p.385390.

BARBOSA, J.A.; VIEIRA, L.B.; DIAS, G.P.; DIAS JÚNIOR, M.S. Desempenho operacional de um trator agrícola equipado alternadamente com pneus radiais e diagonais. Engenharia Agrícola, Jaboticabal, v.25, n.2, p.474-480, 2005.

EMBRAPA. EMPRESA BRASILEIRA DE PESQUISA AGROPECUÁRIA. Centro Nacional de Pesquisa de Solos. Sistema brasileiro de classificação de solos. Rio de Janeiro: Embrapa/CNPS, 2006. 412 p.

GABRIEL FILHO, A.; LANÇAS, K.P.; LEITE, F.; ACOSTA, J.J.B.; JESUINO, P.R. Desempenho de trator agrícola em três superfícies de solo e quatro velocidades de deslocamento. Revista Brasileira de Engenharia Agrícola e Ambiental, Campina Grande, v.14, n.3, p.333-339, 2010 a.

GABRIEL FILHO, A.; MONTEIRO, L.M.; LANÇAS, K.P.; GUERRA, S.P.S.; JESUINO, P.R. Influência da altura das garras dos pneus de um trator em área de plantio direto. Revista Brasileira de Engenharia Agrícola e Ambiental, Campina Grande, v.14, n.10, p.1123-1128, 2010 b.

KHOURY JUNIOR, J.K.; SOUZA, C.M.A.; RAFULL, L.Z.L; VARELLA, C.A.A. Simulação da estabilidade de tratores agrícolas 4 x 2. Bragantia, Campinas, v.68, n.1, p.257-267, 2009.

MÁRQUES, L. Metodologia para cálculo rápido das dimensões de pneus de tratores agrícolas. Engenharia Agrícola, Jaboticabal, v.28, n.3, p.590-603, 2008.

MONTEIRO, L.A.; LANÇAS, K.P.; MASIERO, F.C. Conjuntos: adição de lastro e quando colocar. Panorama Rural, Ribeirão Preto, n.125, p.50-55, jul. 2009.

POTA, H.; KATUPITIYA, J.; EATON, R. Simulation of a tractor-implement model under the influence of lateral disturbances. In: IEEE CONFERENCE ON DECISION AND CONTROL, 46., 2007, New Orleans. Anais... New Orleans: Louisiana State University, 2007. 1 CD-ROM.

SERRANO, J.M.P.R. Desempenho de tratores agrícolas em tração. Pesquisa Agropecuária Brasileira, Brasília, v.42, n.7, p.1021-1027, jul. 2007.

WULFSOHN, D.; UPADHYAIA, S.K.; CHANCELLOR, W.J. Tractive characteristics of radial ply and bias ply tyres in a Califórnia soil. Journal of Therramechanics, Great Britain, v.25, n.2, p.111$134,1988$.

ZOZ, F.M. The cause of powerhop. St Joseph: Michigan. ASABE, 2007. 17 p. (Paper, 071110). 